\title{
SOILS AND FARMING PATTERNS IN THE WAIRARAPA
}

\author{
A. K. Воотн \\ Department of A griculture, M asterton \\ H. S. Gribs \\ Soil Bureau, DSIR, Lower Hutt
}

Since EARLY DAYs, the potential of the Wairarapa as a farming area was realized and New Zealand's first two sheep stations were established here in 1844. Over two-thirds of the Wairarapa is hill country. The remainder is made up of flats in the main valley, in some coastal areas and other smaller river valleys. There are four counties, Eketahuna, Masterton, Wairarapa South and Featherston.

The district is bounded on the west by the Tararua Ranges and on the south and east by the sea. The northern boundary runs east from the Tararua Ranges through the area south of Pahiatua to the sea on the west.

Masterton is the main centre. The smaller towns are Featherston, Martinborough, Greytown, Carterton and Eketahuna. Most of the towns developed during the early days as small subdivisions, some dating back to the early $1850 \mathrm{~s}$. With the improvement in roading and transport, some of the smaller towns have found it difficult to progress.

Access to the Wairarapa has always been a problem and the Rimutaka Ranges have presented both a physical and psychologi. cal barrier.

\section{CLIMATE}

The Wairarapa climate is relatively cold in the winter compared with most other North Island districts, although the grass still grows. The. summer-early autumn period is mostly hot and - dry. In the spring and late autumn, conditions are very good except in some autumns a change from hot and dry to cold and wet can occur very quickly. Seasons can be quite variable and there are often very quick changes with rapid drops in temperature. The prevailing westerly winds are cold in winter because they cross the snow-covered Tararua Ranges. From the south it is 
very exposed and, as the depressions move over the country, strong winds come right up the valley from the deep south.

Annual rainfall varies from 25 in. to well over 100 in. in the high rainfall belt. The Martinborough area, with an annual figure of round $25 \mathrm{in}$., has the lowest rainfall of any area in the North Island. The majority of the district is within the 35 to $50 \mathrm{in}$. range. However, the rainfall effectiveness is much reduced because of the high and persistent winds in many parts of the Wairarapa.

Dry summer and autumn conditions lead to water shortages in large areas of hill country. Provision of adequate water supplies is top priority in the development of East Coast hill country. Many farmers are drought-conscious and this is one of the main factors holding up development. In the last sixty years there have been three occasions when the total rainfall over the three summer months has been only $1 \frac{1 / 2}{2}$ to $2 \frac{1}{2} \mathrm{in}$.

\section{WAIRARAPA SOILS}

The soils of the Wairarapa differ widely in their texture, structure, nutrients, drainage and other properties, primarily as a consequence of changes in the local conditions of formation and of the variety of rock materials occurring on the surface. The broad pattern of these differences is shown on sheet 8 of the General Soil Survey of the North Island (N.Z. Soil Bureau, 1954) and by the classification of the soils into eight groups as follows, the Soil Map numbers being given in parentheses:

Central yellow-grey earths (11cH, 13, 13b, 13bH, 13c, 13d). Central yellow-brown earths $(31 \mathrm{~d}, 31 \mathrm{dH}, 31 \mathrm{e}, 31 \mathrm{f}, 31 \mathrm{fH}, 32 \mathrm{c}$, $32 \mathrm{cH}, 32 \mathrm{~d}, 35 \mathrm{H}, 35 \mathrm{~b}, 35 \mathrm{bH}, 41 \mathrm{aH})$.

Intergrades between the central yellow-brown earths and yellow-grey earths $(25 \mathrm{H}, 25 \mathrm{a}, 25 \mathrm{aH}, 25 \mathrm{c}, 25 \mathrm{cH}, 28,28 \mathrm{H}$, $28 \mathrm{a}, 28 \mathrm{c}, 29,29 \mathrm{H}, 29 \mathrm{e}, 29 \mathrm{fH})$.

Steepland soils associated with above three groups (I 13-124). Intergrades between central yellow-brown earths and yellowbrown loams $(75,75 \mathrm{a}, 75 \mathrm{~b}, 76 \mathrm{c}, 77,77 \mathrm{H}, 77 \mathrm{~b}, 77 \mathrm{bH}, 78$, $78 \mathrm{a}, 78 \mathrm{~b})$.

Central recent soils from alluvium $(1, \mathrm{lb}, \mathrm{lc}, 2)$.

Central gley soils $(106,107 f)$.

Central yellow-brown sands (23).

The natural ability of the soils was mainly for timber production but farmers have explored and developed the agricultural capabilities of large areas by various methods of pastoral and 
crop management. Some soils have given moderate to high levels of agricultural production, some soils only low levels, and some soils have failed to maintain pastures and are now covered with manuka or second growth forest. These contrasting results are not entirely due to soil differences but the soil contribution to past and potential agricultural production can be expressed in a classification of soils into six classes. The classes in order of increasing degrees of soil limitations to high agricultural production are as follows:

Class 1 are the free-draining friable, medium-textured deep soils on river flats and terraces. With fertilizers to supplement the nutrient content and management to maintain organic matter and structure, these soils have a very high potential for agricultural production. They are versatile soils estimated to occupy about 90,000 acres and the maximum area of them should be conserved for intensive farming uses,

Class 2 contains the slow-draining silty soils of the river flats, terraces and downlands totalling about 350,000 acres. Grazing and cropping are limited by periodic waterlogging that cannot be entirely prevented by drainage. Serious deterioration of structure occurs under continuous cropping.

Class 3 includes the stony and shallow soils of the central plains and the sand soils of the lakeside and coastal dunes amounting to about 60,000 acres. Grazing and cropping are limited by periodic shortages of moisture, and maximum use requires either irrigation or farming with soils of Class 2. In a classification of soils for housing or industry, these soils would be in the first class.

Class 4 are soils of hill country that are capable of sustained pastoral grazing with little fertilizer and with slight hazards of erosion. Soils in this class are formed from siltstones, fine sandstones, limestones and greywacke in regions of moderate welldistributed rainfall. They cover about 600,000 acres mainly in a broad strip of hilly and steep land east of the central plains from Longbush to Pahiatua. Smaller areas occur nearer the coast. The grazing potential of these soils under high rates of topdressing and intensive grazing is not known but is expected to be higher than on Te Awa in the Manawatu district (Suckling, 1964).

Class 5 soils are those of hilly and steeplands on which sustained pastoral grazing is limited either by a fairly high requirement for aerial fertilizer applications or by periodic severe shortages 
of moisture or by the hazard of serious erosion. This class includes the steepland soils in regions of seasonally dry climate, and the hill soils derived from coarse sandstone, argillite and bentonitic mudstone. They cover about 550,000 acres in a wide belt east of the Class 4 soils. On the low nutrient fertility hill soils - e.g., $28 \mathrm{H}, 32 \mathrm{cH}$ - the alternatives of timber or grassland production should be considered.

Class 6 soils are those of steeplands liable to rapid or extensive serious erosion under pastoral use. This class contains about 400,000 acres of soils in the Tararua and Aorangi Ranges and on the coastal, argillite range parallel with the East Coast north of Homewood. These soils have a high requirement of fertilizer for pastoral use but applications have been unable to maintain grazable pastures against erosion. Most of these soils should be under forest, mainly in reserves for conservation of water supplies and for recreation.

This classification sets out the agricultural priorities of the soils for consideration in planning the other requirements of the community - the needs for cropping, forestry, housing, industry and recreation. All these competing demands can be satisfied from the soil resources but considerable waste of material, money and work is likely to occur unless soil limitations are taken into account in deciding the land use patterns and practices. This proviso applies particularly to getting maximum benefit from farm management practices which are the major factor in converting the soils to pastoral use.

\section{RESEARCH}

Apart from work on fertilizers and crops, there had been very few investigations into agricultural problems in the Wairarapa prior to 1965. In 1965, the Farm Advisory Division of the Department of Agriculture established the Bideford Demonstration Area where problems of hill country development, and potential carrying capacities and production are being studied. The Masterton Field Research Area was established in 1966 by the Department of Agriculture at East Taratahi. Already valuable information is becoming available. The Grasslands Division, DSIR, is carrying out work on improved pasture species for dry climatic conditions. In the private field, a commercial firm has established the "Arahura" research unit and demonstration farm at Gladstone and on this farm and some others, Soil Bureau, DSIR, is measuring the changes of soil moisture in relation to climate and topography. 


\section{PASTURE PRODUCTION}

There are still many pasture problems in the Wairarapa, in particular there is a lack of species that will produce well under dry summer and cold winter conditions on the developed hill country. White clover, and to a lesser extent subterranean clover, are the main hill country species in conjunction with native grasses. As the fertility and stocking rates are raised, ryegrass tends to move in. There are still some problems of establishment and management of clovers to overcome. Studies are necessary on the affects of inoculation and pelleting of oversown clover seed. Other problems are the economics of applying lime to hill country and the use of molybdenum and its interaction with copper.

\section{WEED AND INSECT PESTS}

Large areas of hill country have reverted to manuka, tauhinu and gorse, particularly in the coastal regions. High labour and freight costs, together with the downward trend of farm incomes, have resulted in the development of large-scale reversion problems. These problems have been accentuated on many farms because, after the annual commitments to absentee owners or estate beneficiaries are met, there. is nothing left for development.

Barley grass is prevalent in the valley region and on some of the easier hill country, and ragwort is a problem on some dairying areas.

Porina and grass grub are serious problems throughout the district. Now that fensulfothion is available at a reduced price, dairy farmers have an efficient alternative treatment to DDT for grass grub control.

Aphids cause serious disease problems in wheat and potatoes and treatment with a systemic organophosphate insecticide is common practice.

\section{SHEEP FARMING}

The large area of hill country has been traditionally breeding country, supplying store stock to farmers on the flat and easy country in the Wairarapa and to other districts. Romney has been the main breed but with labour shortages and lower prices combined with low lambing percentages there have been changes on many hill country farms to the Perendale and to a lesser extent Border Leicester $\mathrm{x}$ Romney cross. The carrying capacity on a lot of clear hill country is as low as $1 \frac{1 / 2}{2}$ to 2 ewes per acre. 
With oversowing and topdressing it is easy to lift it by 3 ewes per acre.

The flats and easy hills are traditionally fat lamb country, but, as the soil fertility rises and the quality of hill country pastures improves, more and more hill country will move from the breeding category into fattening. Breeding from ewe hoggets that are $80 \mathrm{lb}$ or more at mating has been an important development on many farms to improve the net income.

There are nearly 23/4 million sheep in the Wairarapa and the 1972 target figure was passed this year.

\section{BEEF}

Beef cattle have been used in the past to help develop hill country and control surplus growth. Farmers are now realizing that cattle must become a separate enterprise and special allowances made to provide cattle feed during shortage periods. Once high stocking rates are reached with sheep, there is little or no cattle feed available. Drenching for internal parasites and spraying for lice are becoming standard practice and recording body weights is a growing trend. All this is aimed at producing a quality beast in the shortest time while making the fullest use of pasture growth. While in the past large numbers of store cattle were sold to other districts, recent trends are to finish more cattle in the Wairarapa. With the general improvement in management of young stock, the practice of mating of beef heifers to calve as 2-year-olds is now common practice. Aberdeen Angus and Hereford breeds predominate. Beef cattle numbers were slow to pick up after a drought in the early 1960s, but now are up to projected levels.

\section{DAIRYING}

Dairying has been an important industry within the Wairarapa Valley, most of it being in the rain belt along beneath the western ranges. There are intensive pockets on the alluvial soils of the river valleys and around Jake Wairarapa and also a strip of country, much of it originally swampy land, through the middle of the valley, where dairying is carried out. Much of the dairying land outside the high rainfall belt suffers drought conditions during the summer-autumn period and much of it is extremely wet during the winter. Many dairy farmers are using runoffs to advantage on nearby light stony soils, or are able to obtain some off-farm grazing for a period during the winter. Dairy production 
for the Wairarapa is slightly above the national average. Up to $450 \mathrm{lb}$ butterfat per acre is being obtained on the very best farms and there is one herd of 800 cows being milked in a 50 -a-side herringbone shed.

Since the early days, various settlement schemes split much of the dairying land up into very small holdings. As units become uneconomic they are usually bought by neighbouring farmers and amalgamated to make bigger farms.

The number of dairy cattle in Wairarapa included over 50,000 milking cows in 1968 and the 1972 projected level was exceeded in 1966. The numbers are still increasing, with only a very small interest at present being taken by the dairy farmer in beef pro duction. Friesian and Friesian-cross calves are being reared and. grown to beef weights mainly by sheep farmers.

\section{STUD STOCK}

Wairarapa stud stock are well known throughout New Zealand. Romney, Southdown and Perendale sheep studs compete with the best in the country, as do the stud Aberdeen Angus and Hereford beef breeds. Pedigree dairy cattle of the Jersey, Friesian and Ayreshire breeds are also well to the fore.

Perhaps the best known stud stock bred here have been Melbourne Cup winners, Rising Fast and Straight Draw, as well as hosts of other top winners both here and overseas.

\section{CROPPING}

On the silty soils of the valley, in pockets of flat and easy land in river valleys and coastal areas, cropping is carried out in conjunction with sheep farming. Present cash crop production figures for the Wairarapa are approximately:

\section{acres}

\begin{tabular}{|c|c|}
\hline Wheat: & 3,500 \\
\hline Barley: & 5,000 \\
\hline Peas: & 4,000 \\
\hline Potatoes: & 600 \\
\hline oats: & 600 \\
\hline Canary & 1: 400 \\
\hline
\end{tabular}

The Wairarapa produces more ryegrass and red clover seed than any other North Island district and canary seed production is extending. The introduction of the quick-maturing spring 
varieties of Gamenya and Raven wheat has led to marked increases in yield. Autumn sowing of wheat is not very successful unless Arawa is grown. Carlsberg barley is used widely, with Zephyr becoming popular. Peas are grown for seed, and a wide range of garden freezer and field varieties are grown. Of the potatoes grown, Ilam Hardy, Rua and Aucklander Short Top are most popular. There has been a big swing to cropping with the drop in wool prices, and the acreage of individual crops varies according to the current prices.

Winter and summer feed crops are grown on many farms but more reliance is being placed on pasture.

\section{SMALL FRUITS AND MARKET GARDENING}

The deep, free-draining alluvial soils around Greytown have long been used for the production of small fruits such as raspberries, strawberries, loganberries, boysenberries, black currants and gooseberries. The district produces $80 \%$ of New Zealand's gooseberries and $20 \%$ of the loganberries and black currants. There are also a number of apple orchards.

Vegetable growing is carried out in many places along the silty alluvial flats in the valley area, most being grown for local and Wellington markets. The Lake Development Scheme may make a considerable area available for market gardening, but damage from wind and frost could be a big danger.

\section{PIGS AND POULTRY}

Pig and poultry farming are carried out to a limited extent and, although markets are few, the proximity to large graingrowing areas could be a big advantage in the future.

\section{SERVICING INDUSTRIES}

TRANSPORT

Road and rail transport are readily available. Upgrading back country roads and good road access to Wellington are priorities, along with some improved rail facilities.

\section{SALEYARDS}

The saleyards are strategically placed at Waingawa in close proximity to freezing works and main access routes for rail and road transport. Martinborough also has major stock sales, and there are minor ones at Eketahuna and Carterton. 


\section{FREEZING WORKS}

The Waingawa Freezing Works is the main meat works but a large number of stock are transported to freezing works in the Wellington area for killing.

\section{FERTILIZER WORKS}

The initial stage of a fertilizer works has been established south of Waingawa and is being used as a bulk store at present for fertilizer manufactured at Napier. When demand rises, fertilizer will be manufactured here with acid made at Napier. The longterm plan is to carry out the whole process here. The Wanganui works also supply fertilizer to the district.

\section{LIME WORKS}

Three main lime works operate at Mauriceville, Weraiti and Pakohe and produce high quality lime. There are also a number of private lime pits.

\section{DAIRY FACTORIES}

Three dairy companies process all the dairy products. While amalgamation has been going on for a long time, two main companies together with a smaller company operate five dairy factories producing butter, cheese, and casein. Many of the small dairy factories, closed because of amalgamation, are being put to good use, some for mushroom production,

Twenty-one town miik producers supply local requirements to the milk treatment station in Masterton.

\section{WOOL}

While some private buyers operate in the Wairarapa, the bulk of the wool goes into store in Wellington before sale. The Wairarapa may not benefit from wool handling facilities, but it certainly does from the internationally known Golden Shears Competition held in Masterton each year,

\section{OTHER INDUSTRIES}

Other industries include items such as stock foods, wool presses, sheep and cattle weighing scales, pipes and tiles, machinery and equipment, electrical and refrigeration products, plastics and a host of others. If developed, the Wairarapa has a big potential for tourist and holiday resorts, 


\section{THE FUTURE}

History, location, climate and soil have in the past put a number of restrictions on the development of farming in the Wairarapa. However, sufficient is already known to overcome many of these problems. Research, demonstration areas, and our top farmers are showing the way. All we need now is to further research and present a bold and united effort to further the interests of the Wairarapa as a whole, and not the individual interest of towns, organizations or particular sections of the community. Let us challenge the future with confidence, and realize the unlimited potential there is in the soils and people of the Wairarapa.

\section{REFERENCE}

N.Z. Soil Bureau, N.Z. Soil Bureau Bull, (n.s.) 5. 286 pp.

Suckling, F. E. T., 1964: Sheepfmg A., 18-32.

\section{DISCUSSION}

Langer suggested that there was little tie-up between separate enterprises in Wairarapa - e.g., dairying and beef, cropping and livestock. In reply, Booth stated that, as far as dairy-beef was concerned, there were problems of supply of Friesians and many farmers had had little success except where both dairy and sheep farmers had co-operated. Barley was grown extensively and much of it was used locally. There was only a limited field for poultry and pigs.

Brougham observed that water was a major problem in the area from November to April but there were no data on water loss. He felt that such basic data should be collected to enable improved water utilization as was done in Australia. Booth and Gibbs agreed that this was an important problem but that such operations were expensive and needed much labour. Brougham then suggested that a network of 30 to 40 evaporimeters should be possiblc, that it would not have a high labour requirement, and that the information provided would be most valuable. Gibbs stated that measurements of soil water loss had been made at Arahura and Ponatahi over an 18-month period.

To a suggestion that lucerne should be more widely grown, Booth replied that it grew best in free-draining soils which would perhaps be better used for other crops. On stony soils, lucerne was not very successful because it did not seem to root decply and so did not reach the watertable.

Ludecke said it had been suggested. that Class V soils should be in forestry but he contended that, if targets were to be reached, they should remain in agricultural production. Gibbs agreed that Taihape soil should be a grassland soil but it was most unstable and therefore difficult to use permanently for pasture. Forestry must be an alternative and it was also a productive export.

Burgess stated that water relationship problems were present in the whole area, particularly on east coast hill soils. It was essential that information should be related to pasture species being tested by Grasslands Division in co-operative projects so that suitable species for the area could perhaps be found. 